Aquaculture

January 2019, Volume 499 Pages 373-373

https://doi.org/10.1016/j.aquaculture.2018.08.048

Archimer

https://archimer.ifremer.fr/doc/00464/57536/

\title{
A scientific name for Pacific oysters
}

Bayne B., D'Auriac M. Angles ${ }^{1}$, Backeljau T. ${ }^{2}$, Beninger P. ${ }^{3}$, Boudry Pierre ${ }^{4}$, Carnegie R. ${ }^{5}$, Davis J. 6 , Guo X. ${ }^{7}$, Hedgecock D. ${ }^{8}$, Krause M. ${ }^{9}$, Langdon C. ${ }^{10}$, Lapegue Sylvie ${ }^{11}$, Manahan D. ${ }^{11}$, Mann R. ${ }^{5}$, Powell E. ${ }^{12}$, Shumway S. 13

${ }^{1}$ Norwegian Inst Water Res NIVA, Gaustadalleen 21, N-0349 Oslo, Norway.

2 Royal Belgian Inst Nat Sci, Vautierstr 29, B-1000 Brussels, Belgium.

3 Univ Nantes, MMS, Lab Biol Marine, 2 Rue Houssiniere, F-44322 Nantes, France.

${ }^{4}$ CNRS UBO IRD Ifremer, IFREMER, LEMAR UMR 6539, F-29280 Plouzane, France.

${ }^{5}$ Coll William \& Mary, Virginia Inst Marine Sci, POB 1346, Gloucester Point, VA 23062 USA.

${ }^{6}$ Baywater Shellfish Farm, 10610 NE Manitou Pk Blvd, Bainbridge Isl, WA 98110 USA.

${ }^{7}$ Rutgers State Univ, Haskin Shellfish Res Lab, Dept Marine \& Coastal Sci, 6959 Miller Ave, Port Norris, NJ 08349 USA.

8 Univ Southern Calif, Dept Biol Sci, 3616 Trousdale Pkwy,AHF 107, Los Angeles, CA 90089 USA.

${ }^{9}$ Hofstra Univ, 114 Hofstra Univ, Hempstead, NY 11549 USA.

10 Oregon State Univ, Hatfield Marine Sci Ctr, 2030 SE Marine Sci Dr, Newport, OR 97365 USA.

11 IFREMER, LGPMM, Ave Mus de Loup, F-17390 La Tremblade, France.

12 Univ Southern Mississippi, Gulf Coast Res Lab, 703 East Beach Dr, Ocean Springs, MS 39564 USA.

13 Univ Connecticut, Dept Marine Sci, 1080 Shennecossett Rd, Groton, CT 06340 USA.

Email addresses : baynebrian@hotmail.com ; mad@niva.no ; tbackeljau@naturalsciences.be ;

Peter.Beninger@univ-nantes.fr ; Pierre.Boudry@ifremer.fr ; carnegie@vims.edu ;

jothpdavis@gmail.com ; xguo@hsrl.rutgers.edu ; dhedge@usc.edu ; Maureen.K.Krause@hofstra.edu ; chris.langdon@oregonstate.edu ; Sylvie.Lapegue@ifremer.fr ; manahan@usc.edu ;

sandra.shumway@uconn.edu ; eric.n.powell@usm.edu 
Dear Editor,

We write concerning the scientific name for the Pacific oyster used by Aquaculture. An article in the 1 October issue (Ugalde et al. 2018) presents the binomial for the Pacific oyster as "Magallana gigas, previously known as Crassostrea gigas," citing Salvi et al. (2014).

The suggestion by Salvi et al. (2014) and Salvi and Mariottini (2017) that the genus Crassostrea, as applied to cupped oysters of Pacific origin (e.g., Crassostrea gigas, the Pacific oyster), be replaced by the genus Magallana has been greeted with dismay by researchers and aquaculturists alike. Bayne et al. (2017) have recently published a short dissenting view, calling the suggestion "disruptive and destabilizing."

The World Register of Marine Species (WoRMS) initially disseminated the proposed genus change. On receipt of our "dissenting view," WoRMS re-instated Crassostrea but in a way that, we believe, confuses the situation. WoRMS now describes Crassostrea (as of 25 July 2018) as an "alternate representation," which it defines as "an accepted name...but slightly less preferred." The basis for this 'preference' is not clear, but its assertion is not a scientific resolution of the taxonomic conflict for this important aquaculture species.

We anticipate that the majority of researchers will continue to refer to the Pacific oysters as Crassostrea. Indeed, since Salvi and Mariottini (2017), only 11 papers in 10 journals have used Magallana gigas, while over 700 papers in over 200 journals used Crassostrea gigas (Web of Science). Nevertheless, there is potential for confusion to spread among researchers, including young scientists who are publishing for the first time.

We ask that you require manuscripts submitted for publication to use Crassostrea as the accepted genus for all Pacific and Atlantic cupped oysters, until a more detailed and comprehensive genomic analysis resolves the correct nomenclature. In the interim, this conservative taxonomic usage will help to avoid misunderstanding, anxiety and disorder.

\section{References:}

Bayne, B.L. and 26 co-authors. 2017. The proposed dropping of the genus Crassostrea for all Pacific cupped oysters and its replacement by a new genus Magallana: a dissenting view. Journal of Shellfish Research 36(3), 545-547.

Salvi, D., Macali, A., Mariottini, P., 2014. Molecular phylogenetics and systematics of the bivalve family Ostreidae based on rRNA Sequence-Structure Models and Multilocus Species Tree Associated Data. PLOS ONE, 9, Article Number: e108696.

Salvi, D., Mariottini, P., 2017. Molecular taxonomy in 2D: a novel ITS 2 rRNA sequence structure approach guides the description of the oysters' subfamily Saccostreinae and the genus Magallana (Bivalvia: Ostreidae). Zoological Journal of the Linnean Society 179, 263-276.

Ugalde, S.C., Preston, J., Ogiera, E., Crawford, C., 2018. Analysis of farm management strategies following herpesvirus (OsHV-1) disease outbreaks in Pacific oysters in Tasmania, Australia. Aquaculture 495, 179-186. 